\title{
Örjan Lindberger in memoriam
}

I slutet av juni avled professor Örjan Lindberger, 92 år gammal. Han var ordförande i Svenska barnboksinstitutets styrelse i mer än tio år.

Barnböcker och vuxenlitteratur är titeln på en av Örjan Lindbergers uppsatser. Gränserna mellan dessa litteraturformer är inte absoluta, skriver han insiktsfullt, och det var något som han höll på från början. Han diskuterade äventyrsböcker i litterära radioprogram på 1940-talet, och på 1960-talet ventilerades ett dussintal uppsatser om barn- och ungdomslitteratur på hans trebetygsseminarium, bland annat en om Tove Janssons muminböcker. Det var nytt och helt unikt inom den litteraturhistoriska världen i Sverige. Ämnet hette" litteraturhistoria med poetik" under större delen av 1960-talet det var först 1968 som ämnesbeteckningen byttes till litteraturvetenskap. Att barn - och ungdomslitteraturen fick utrymme inom litterär historik och poetik och utsattes för analys och tolkning var för många omstörtande. Men Örjan Lindbergers barnlitteraturseminarier fick stor genomslagskraft. Genom hans arbete kom den process igång som banade väg för undervisning och forskning vid litte- raturvetenskapliga institutionen i Stockholm, något som också ledde till att en professur i litteraturvetenskap, särskilt barnoch ungdomslitteratur, inrättades vid universitetet 1982.

Örjan Lindberger var en sann barnlitterär aktivist, verksam på en rad samverkande frontlinjer. Han var central som forskningsoch seminarieledare och gav år 1970 ut antologin Barnlitteratur i Sverige i samarbete med Lars Furuland och Mary Ørvig, en textsamling som snabbt etablerade sig som en klassiker på det nya ämnesområdet. Han var med i bildandet av Stiftelsen Svenska barnboksinstitutet, tillsammans med Lennart Hellsing och Hans Rabén, och blev universitetets förste representant $i$ styrelsen. Han utsågs till ordförande 1968.

Det för mig mest beundransvärda är ändå hur litteraturprofessorn Örjan Lindberger på ett alldeles naturligt sätt förde in en ny kategori av litterära texter på den akademiska arenan. För honom behövdes inga utredningar, inga sammanträden, inga byråkratiska beslut. Bara ett öppet sinne och en fri syn på litteratur.

Boel Westin 